\title{
A Novel Superantigen Isolated from Pathogenic Strains of Streptococcus pyogenes with Aminoterminal Homology to Staphylococcal Enterotoxins B and C
}

\author{
Joseph A. Mollick, " Geraldine G. Miller, ${ }^{\star}$ James M. Musser, ${ }^{*}$ Richard G. Cook, " Douglas Grossman, * and Robert R. Rich *\| \\ Departments of * Microbiology and Immunology, "Medicine, and ${ }^{8}$ Pathology, Baylor College of Medicine, Houston, Texas 77030; and \\ ${ }^{\ddagger}$ Department of Medicine, Vanderbilt University School of Medicine, Nashville, Tennessee 37232
}

\begin{abstract}
Streptococcus pyogenes (group A Streptococcus) has reemerged in recent years as a cause of severe human disease. Because extracellular products are involved in streptococcal pathogenesis, we explored the possibility that a disease isolate expresses an uncharacterized superantigen. We screened culture supernatants for superantigen activity with a major histocompatibility complex class II-dependent $\mathbf{T}$ cell proliferation assay. Initial fractionation with red dye $A$ chromatography indicated production of a class II-dependent $\mathrm{T}$ cell mitogen by a toxic shock-like syndrome (TSLS) strain. The amino terminus of the purified streptococcal superantigen was more homologous to the amino termini of staphylococcal enterotoxins $B, C_{1}$, and $\mathrm{C}_{3}\left(\mathrm{SEB}, \mathrm{SEC}_{1}\right.$, and $\left.\mathrm{SEC}_{3}\right)$, than to those of pyrogenic exotoxins $A, B, C$ or other streptococcal toxins. The molecule, designated SSA, had the same pattern of class II isotype usage as SEB in $\mathrm{T}$ cell proliferation assays. However, it differed in its pattern of human $T$ cell activation, as measured by quantitative polymerase chain reaction with $\mathrm{V} \beta$-specific primers. SSA activated human $T$ cells that express $V \beta 1,3,15$ with a minor increase of $V \beta 5$.2-bearing cells, whereas SEB activated V $\beta 3,12$, 15 , and 17-bearing $T$ cells. Immunoblot analysis of 75 disease isolates from several localities detected SSA production only in group A streptococci, and found that SSA is apparently confined to only three clonal lineages as defined by multilocus enzyme electrophoresis typing. Isolates of one of these lineages, (electrophoretic type 2) are strongly associated with TSLS. The data identify SSA as a novel streptococcal superantigen that appears to be more related structurally to staphylococcal enterotoxins than to streptococcal exotoxins. Because abundant SSA production is apparently confined to only three streptococcal clonal lineages, the data also suggest that the SSA gene has only recently been acquired by $S$. pyogenes. (J. Clin. Invest. 1993. 92: 710-719.) Key words: bacterial exotoxin • staphylococcal enterotoxin - Streptococcus pyogenes $\bullet$ superantigen $-T$ cell receptor $V \beta$ segment
\end{abstract}

\section{Introduction}

In recent years, the United States has experienced a resurgence of severe, streptococcal infections, including toxic shock-like

This study was presented in part at the 1992 annual meeting of the Association of American Physicians, Baltimore, MD.

Address reprint requests to Dr. Robert R. Rich, Immunology Section, M929, Baylor College of Medicine, One Baylor Plaza, Houston, TX 77030 .

Received for publication 4 January 1993 and in revised form 15 March 1993.

J. Clin. Invest.

(C) The American Society for Clinical Investigation, Inc.

0021-9738/93/08/0710/10 \$2.00

Volume 92, August 1993, 710-719 syndrome (TSLS) ${ }^{1}$ and acute rheumatic fever (1-3). Although the occurrence of several streptococcal virulence factors has been examined, no streptococcal molecule has been implicated as the sole cause of these diseases, a finding that presumably reflects the involvement of multiple bacterial products.

Bacterial superantigens, characteristically produced by Gram-positive cocci such as Staphylococcus aureus and Streptococcus pyogenes, may play a central role in disease pathogenesis. Superantigens are mitogens that activate $T$ cells in a specific manner. These proteins bind to MHC class II molecules and activate $T$ cells bearing one or few types of variable segments in their T cell receptor (TCR) $\beta$ chain (4-8). By virtue of this mechanism, $1-5 \%$ of peripheral $\mathrm{T}$ cells potentially respond to individual toxins. It has been proposed that several streptococcal and staphylococcal toxin-mediated diseases are caused, at least in part, by release of $\mathrm{T}$ cell cytokines $(9,10)$.

$S$. pyogenes produces several extracellular virulence factors that include pyrogenic exotoxins A, B, and C (SPE-A, B, and $C)$, and evidence exists that SPE-A and SPE-C are superantigens (11-13). There is controversy about the assignment of superantigen status to SPE-B, a protein that may be an allele of streptococcal cysteine proteinase (SP) (14). A large percentage of $S$. pyogenes strains from patients with severe invasive infections produce SPE-A (scarlet fever toxin) and it is probable that SPE-A is involved in the pathogenesis of many TSLS cases $(3,15)$. However, because the molecular mechanism of severe streptococcal diseases is not fully understood, we examined pathogenic strains for ability to express additional superantigens.

In this article we describe isolation and characterization of a novel streptococcal superantigen from two group A streptococcal strains that caused TSLS. Interestingly, this new molecule exhibits striking $\mathrm{NH}_{2}$-terminal sequence homology to staphylococcal enterotoxin $B, C_{1}$, and $C_{3}\left(S E B, S E C_{1}\right.$, and $\left.S C_{3}\right)$ rather than to characterized streptococcal products. Expression of this molecule by one of the two streptococcal clones that cause the majority of severe streptococcal disease in adult humans suggests that this superantigen may be a virulence factor in streptococcal diseases.

\section{Methods}

Bacterial strains. During the initial phase of this study, SSA was obtained from group A streptococcal strain Weller (serotype M3). This organism and strain Gall (serotype M1) were recovered from patients with fatal TSLS and were provided by Dennis L. Stevens, Veterans Affairs Hospital, Boise, ID. These strains also carry the designations DLS88002 (Weller) and DLS89026 (Gall) and both produce SPE-A (Dennis L. Stevens, personal communication). In the course of our investigation, we identified a second strain, MGAS 158 (15), that pro-

1. Abbreviations used in this paper: RDA, red dye A; SE, staphylococcal enterotoxin; SP, streptococcal cysteine proteinase; SPE, S. pyrogenes exotoxin; TCR, T cell receptor; TSLS, toxic shock-like syndrome. 
duced higher levels of SSA than strain Weller. The purification strategy developed for Weller supernatants was applied to strain MGAS 158 with similar resulting purification of SSA. Additional organisms used in this study included 58 strains of $S$. pyogenes recovered from patients with contemporary episodes of invasive disease and TSLS (15), 11 strains of $S$. pyogenes cultured from children with pharyngitis (16), 8 strains of $S$. agalactiae from neonates with invasive disease (group B Streptococcus) (17), 2 strains each of $S$. equi and $S$. zooepidemicus from diseased horses (group C Streptococcus), and 3 strains of group G Streptococcus from diseased humans (18).

Production of anti-SSA $A b$. A peptide ( $\mathrm{NH}_{2}$-CGGSSQPDPTPEQLNKSSQFTG-COOH) was synthesized that corresponded to the $\mathrm{NH}_{2}$-terminal 19 amino acids of SSA. The peptide included a diglycine spacer and amino-terminal cysteine to facilitate coupling. A peptidecarrier conjugate was prepared with the Imject Activated Supercarrier System (No. 77156, Pierce Chemical Co., Rockford, IL). Aliquots $(100 \mu \mathrm{g})$ of the peptide-carrier conjugate were emulsified in complete Freund's adjuvant and injected into rabbits. The animals were boosted and bled at alternating 2-wk intervals (Bethyl Laboratories, Montgomery, TX). After $4 \mathrm{wk}$, the serum contained anti-SSA peptide activity as assayed by ELISA. To recover anti-peptide IgG, rabbit immune serum was diluted 1:1 in PBS and passed through a peptide-conjugated Sepharose 4B column (HR 10/10 column, 5-ml bed volume, Pharmacia, Inc., Piscataway, NJ). The column was washed to background absorbance $\left(A_{280}\right)$, eluted with $0.1 \mathrm{M}$ glycine, $\mathrm{pH} 2.4$, and the eluate immediately neutralized with $1 \mathrm{M}$ Tris base, $\mathrm{pH} 9.5$. The anti-peptide antibodies (Abs) were diluted 1:1 in Immunopure (G) binding buffer (Pierce Chemical Co.) and passed through a 1.6-ml protein G column. The IgG was eluted with Immunopure elution buffer (Pierce Chemical Co.) and neutralized immediately.

Purification of SSA. 16 liters of chemically defined media/2\% Todd-Hewitt broth were inoculated with $150 \mathrm{ml}$ of an overnight culture of strain MGAS 158. Chemically defined media broth consisted of $27.1 \mathrm{~g} /$ liter chemically defined media (JRH Biosciences, Lenexa, KS) supplemented with $2.5 \mathrm{~g}$ /liter sodium bicarbonate and $0.5 \mathrm{~g} /$ liter Lcysteine. Components were mixed in water at room temperature, supplemented with Todd-Hewitt broth, and filtered $(0.45 \mu \mathrm{m})$. Stationary cultures were incubated at $37^{\circ} \mathrm{C}$ in a humidified environment supplemented with $5 \% \mathrm{CO}_{2}$ for $24 \mathrm{~h}$ and harvested by centrifugation. The supernatant was filtered $(0.45 \mu \mathrm{m})$ and sodium azide $(0.05 \% \mathrm{wt} / \mathrm{vol})$ was added. Supernatants were concentrated to $\sim 50 \mathrm{ml}$ at $4^{\circ} \mathrm{C}$ on YM10 (10-kD cutoff) membranes (Amicon Corp., Danvers, MA). The material was dialyzed against a total of 12 liters of $20 \mathrm{mM}$ sodium phosphate buffer, $\mathrm{pH} 6.8$, for $\sim 24 \mathrm{~h}$. The dialyzate was again filtered $(0.45 \mu \mathrm{m})$ and supplemented with sodium azide.

A red dye A (RDA) (Amicon Corp.) column $(1.5 \times 20 \mathrm{~cm}, 30-\mathrm{ml}$ bed volume) was prepared by stripping the matrix with three column volumes of $8 \mathrm{M}$ urea in $0.5 \mathrm{M} \mathrm{NaOH}$, and the column was equilibrated with $20 \mathrm{mM}$ sodium phosphate buffer, $\mathrm{pH} 6.8$. The concentrated supernatant was passed through this column twice at a flow rate of 18 $\mathrm{ml} / \mathrm{h}$ at room temperature and the column was washed to background absorbance ( $280 \mathrm{~nm}$ ) with $20 \mathrm{mM}$ sodium phosphate buffer. The column was eluted with two column volumes each of a step gradient of 60 , 150,300 , and $500 \mathrm{mM}$ sodium phosphate, $\mathrm{pH} 6.8$, and the elution profile was monitored with an $A_{280}$ UV detector. Fractions $(12 \mathrm{ml}$ ) were collected and assayed for class II-dependent $T$ cell mitogenic activity (7). Active fractions were pooled and concentrated to $3 \mathrm{ml}$ using a Centriprep and Centricon 10 concentrators (Amicon Corp.). The material was buffer exchanged into PBS using a DG-10 column (Bio-Rad Laboratories, Richmond, CA) and passed twice over an anti-SSA IgG conjugated Sepharose column (3-ml bed volume). The anti-SSA IgG was conjugated at a concentration of $4 \mathrm{mg} \mathrm{IgG} / \mathrm{ml}$ Sepharose using a directional coupling system (Affinica, Schleicher \& Schuell, Inc., Keene, NH). The column was washed to background absorbance $\left(A_{280}\right)$ using PBS and eluted with $0.1 \mathrm{M}$ sodium acetate and $0.5 \mathrm{M}$

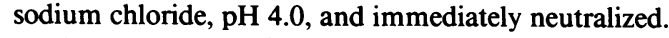

Determination of amino-terminal sequence. The product of the eluate from the anti-SSA Ab column $(\sim 10 \mu \mathrm{g})$, or a sequential chro- matography protocol ( $\sim 30 \mu \mathrm{g})$ was dissolved in SDS buffer $(62.5 \mathrm{mM}$ Tris, $10 \%$ [vol/vol] glycerol, $3 \%$ [wt/vol] SDS, $5 \%$ [vol/vol] 2-mercaptoethanol ), boiled for $5 \mathrm{~min}$, and loaded onto a 12.5\% SDS-PAGE gel $(12 \mathrm{~cm} \times 16 \mathrm{~cm} \times 1.5 \mathrm{~mm})$ that had been aged $24 \mathrm{~h}$. The upper buffer was supplemented with $0.1 \mathrm{mM}$ thioglycolate and the samples were electrophoresed at $35 \mathrm{~mA}$ for $5.5 \mathrm{~h}$. The gel was blotted to Problott (Applied Biosystems, Inc., Foster City, CA) at $90 \mathrm{~V}$ for $30 \mathrm{~min}$ at $4^{\circ} \mathrm{C}$ in $10 \mathrm{mM} \mathrm{3-[cyclohexylamino]-1-propanesulfonic} \mathrm{acid,} 10 \%$ methanol, $\mathrm{pH} 11$, and stained with Coomassie Blue according to the manufacturer's instructions. An Applied Biosystems 473A protein sequencer was used to determine the $\mathrm{NH}_{2}$ terminus of the excised bands.

Determination of VB segment usage with quantitative PCR. Purified T cells from two donors were stimulated with SSA $(2 \mu \mathrm{g} / \mathrm{ml})$, SEB $(1 \mu \mathrm{g} / \mathrm{ml})$, or PHA $(1 \mu \mathrm{g} / \mathrm{ml})$ for three days. Mitomycin-treated DR 1transfected $\mathrm{L}$ cells were used as a source of class II molecules. Viable cells were isolated on an Isolymph gradient (Gallard-Schlesinger Industries, Carle Place, NY) and recultured for $24 \mathrm{~h}$ with $25 \mathrm{U} / \mathrm{ml} \mathrm{rIL-2}$ (Amgen Biologicals, Thousand Oaks, CA). The cells were washed once with HBSS and pelleted. The cells were stored at $-70^{\circ} \mathrm{C}$ until RNA was extracted. Total cellular RNA was prepared (19) and PCR was performed as described previously (20). Specific $V \beta$ oligonucleotide primers were kindly provided by Dr. Michael Brenner (Harvard University, Cambridge, MA) and had the same coding sequences as previously described $(20)$ but included an added Sall cleavage site at the $5^{\prime}$ end. The $3^{\prime}$ primers were labeled using polynucleotide kinase (New England Biolabs, Beverly, MA) and $\left[\gamma-{ }^{32} \mathrm{P}\right]$ ATP. First strand template was combined with the $\mathrm{C} \alpha$ and $\mathrm{C} \beta$ primers, Taq polymerase, nucleotides and buffer, and aliquots were transferred to each of 22 tubes containing the $\mathrm{V} \beta$-specific oligonucleotide primers. Amplification was carried out for 25 cycles at $94^{\circ} \mathrm{C}$ for $1 \mathrm{~min}, 55^{\circ} \mathrm{C}$ for $1 \mathrm{~min}$, and $72^{\circ} \mathrm{C}$ for $1 \mathrm{~min} .10 \mu \mathrm{l}$ of the reaction mixture were electrophoresed in a $2 \%$ agarose gel, and the gels were dried and autoradiographed. The autoradiograms were analyzed with a densitometer (model EC 910, E-C Apparatus Corp., St. Petersburg, FL) and the areas under the curves were derived with the GS370 Electrophoresis Data system program (Hoefer Scientific Instruments, San Francisco, CA). The data are presented as the ratio of the area of the $\mathrm{V} \beta$ product to the area of the $\mathrm{C} \alpha$ product.

Determination of class II isotype usage. Twofold dilutions of partially purified SSA were incubated with highly purified T cells $\left(6 \times 10^{4}\right.$ per well $)$ and $\mathrm{L}$ cells $\left(3 \times 10^{4}\right.$ per well) transfected with the genes encoding DR4 (L165.1), DQ7 $\alpha / 3 \beta$ (L54), DP4 (L25.1), I-E ${ }^{\text {d }}$ (RT $10.3 \mathrm{~B}-\mathrm{C} 1)$, I-A ${ }^{\mathrm{d}}(\mathrm{RT} 2.3 .3 \mathrm{H}-\mathrm{D} 6)$, or the neomycin resistance gene only (L66), as previously described (7). Cultures were incubated in flat-bottom 96-well plates for $90 \mathrm{~h}$ and labeled with $1 \mu \mathrm{Ci}$ of $\left[{ }^{3} \mathrm{H}\right]-$ thymidine for the final $18 \mathrm{~h}$.

Immunoblot detection of SSA. Streptococcal organisms were grown for $24 \mathrm{~h}$ in chemically defined media $/ 2 \%$ Todd-Hewitt broth, and supernatants harvested by centrifugation and filtration $(0.45 \mu \mathrm{m})$. Supernatant samples $(3 \mathrm{ml})$ were precipitated by addition of $4 \mathrm{vol}$ of ethanol and centrifuged at $16,000 \mathrm{~g}$. The precipitate was solubilized in $300 \mu \mathrm{l}$ of SDS buffer plus 2-mercaptoethanol, boiled for $5 \mathrm{~min}$ and centrifuged at $14,000 \mathrm{~g}$ for $10 \mathrm{~min}$ to remove precipitate. Samples $(50 \mu \mathrm{l})$ were electrophoresed through a $10 \%$ SDS-PAGE gel $(120 \times 160 \times 1.5 \mathrm{~mm})$. Gels were blotted to Hybond C (Amersham Corp., Arlington Heights, IL) at $30 \mathrm{~V}$ for $10 \mathrm{~h}$ and $50 \mathrm{~V}$ for the final $2 \mathrm{~h}$ in Towbin transfer buffer (21). The blots were dried, blocked for $2 \mathrm{~h}$ in PBS $/ 2 \%$ BSA at $25^{\circ} \mathrm{C}$ and washed extensively. Duplicate blots were probed overnight at $4^{\circ} \mathrm{C}$ with anti-SSA-Ig conjugated directly to horseradish peroxidase in the presence of $100 \mu \mathrm{g} / \mathrm{ml}$ of either the immunizing peptide, SSA (1-19), or a control peptide from ragweed allergen, $\operatorname{Ra3}$ (54-67) peptide, (22). The blots were developed with the ECL chemiluminescence detection system (Amersham Corp.).

\section{Results}

Purification of SSA from S. pyogenes strain Weller. Because RDA has been used to purify several staphylococcal enterotox- 
ins $(23,24)$, we thought this material might be useful in identifying novel $S$. pyogenes superantigens. Concentrated culture supernatants from strain Weller were chromatographed on a RDA column, the column was eluted with a phosphate step gradient, and fractions were tested for the presence of a class II-dependent $T$ cell mitogen (7). We identified such an activity eluting between 60 and $150 \mathrm{mM} \mathrm{PO}_{4}$, corresponding approximately to fraction numbers $8-55$ (Fig. 1). This activity eluted in a broad peak and did not correspond to a detectable protein peak. Examination of an aliquot of the pooled activity by SDS-PAGE gel revealed many proteins, some in the $30-\mathrm{kD}$ range (data not shown). We then fractionated the pooled active fractions from the RDA column by gel filtration (G-75) and anion exchange chromatography and selected active fractions from each column. The product from the final chromatography step consisted predominantly of three proteins (Fig. 2 $A$ ). The proteins were blotted to a solid support and analyzed by $\mathrm{NH}_{2}$-terminal sequencing. The higher $M_{\mathrm{r}}$ protein was identified as SP and/or SPE-B (14). These two proteins are closely similar and cannot be distinguished based on the 29 amino acids sequenced. The lower $M_{\mathrm{r}}$ protein, $\sim 27 \mathrm{kD}$ in size, yielded a 59-amino acid $\mathrm{NH}_{2}$ terminus that was not notably homologous to any previously characterized protein. The middle band $(28 \mathrm{kD})$ displayed an $\mathrm{NH}_{2}$ terminus strikingly similar to the $\mathrm{NH}_{2}$ termini of SEB, $\mathrm{SEC}_{1}$, and $\mathrm{SEC}_{3}$ and dissimilar to $M$ protein (Fig. 3). The $28-\mathrm{kD}$ molecule with the SEB-like $\mathrm{NH}_{2}$ terminus was designated SSA.

Purification of SSA by Ab affinity chromatography. To determine whether or not SSA was responsible for the superantigen activity, we focused our efforts on its purification. An antipeptide antiserum was raised against the first 19 amino acids of SSA. To determine the ability of the anti-SSA Abs to bind native SSA, a concentrated streptococcal supernatant from 16 liters was chromatographed on RDA in an effort to enrich for
SSA. The RDA eluate was passed over the anti-SSA Ab column and the column eluted. Examination of the eluate by SDS-PAGE gel, and silver stain identified one prominent band at $28 \mathrm{kD}$, and two minor bands, one at $\sim 25 \mathrm{kD}$ and one at $\sim 12 \mathrm{kD}$ (Fig. $2 \mathrm{~B}$, lane 1 ). $\mathrm{NH}_{2}$-terminal sequencing of the 28-kD product identified the $\mathrm{SSA} \mathrm{NH}_{2}$ amino terminus shown in Fig. 3. To determine whether the lower $M_{\mathrm{r}}$ species were contaminants or SSA degradation products, we subjected an identical sample to immunoblot analysis. Anti-SSA antibodies detected all three species shown in the silver stain gel, indicating that these lower molecular weight bands were breakdown products of the $28-\mathrm{kD}$ protein. Because the antibodies were directed against the $\mathrm{NH}_{2}$ terminus, these products likely represent SSA molecules missing $\mathrm{COOH}$ terminal sections.

To test whether SSA had superantigen activity, we examined the ability of SSA to stimulate $T$ cell proliferation in a class II-dependent fashion. Purified SSA (identical to that shown in Fig. $2 B$ ) displayed potent mitogenic activity that was entirely dependent on the presence of MHC class II molecules (Fig. 4). These data demonstrate that class II-dependent $T$ cell proliferative activity can be assigned to the SSA molecule and is not due to some contaminating protein such as SPE-A, SPE-B, or M protein.

SSA and SEB have similar MHC class II isotype specificity. Some superantigens exhibit variable patterns with respect to the MHC class II isotypes to which they bind $(25,26)$. The ability of a superantigen to bind a given class II isotype can be measured directly in a binding assay, or indirectly by examining its ability to activate $\mathrm{T}$ cells in the context of that class II isotype molecule. The class II isotype specificity of SSA was tested with human $T$ cells and mouse $L$ cells that had been transfected with genes encoding HLA-DR4, DQ7 $\alpha / 3 \beta$ or DP4, or $\mathrm{H}-2 \mathrm{IA}^{\mathrm{d}}$ or IE ${ }^{\mathrm{d}}$. The results demonstrated that SSA activated $T$ cells in the context of HLA-DR, DQ, and H-2 I-E, but not

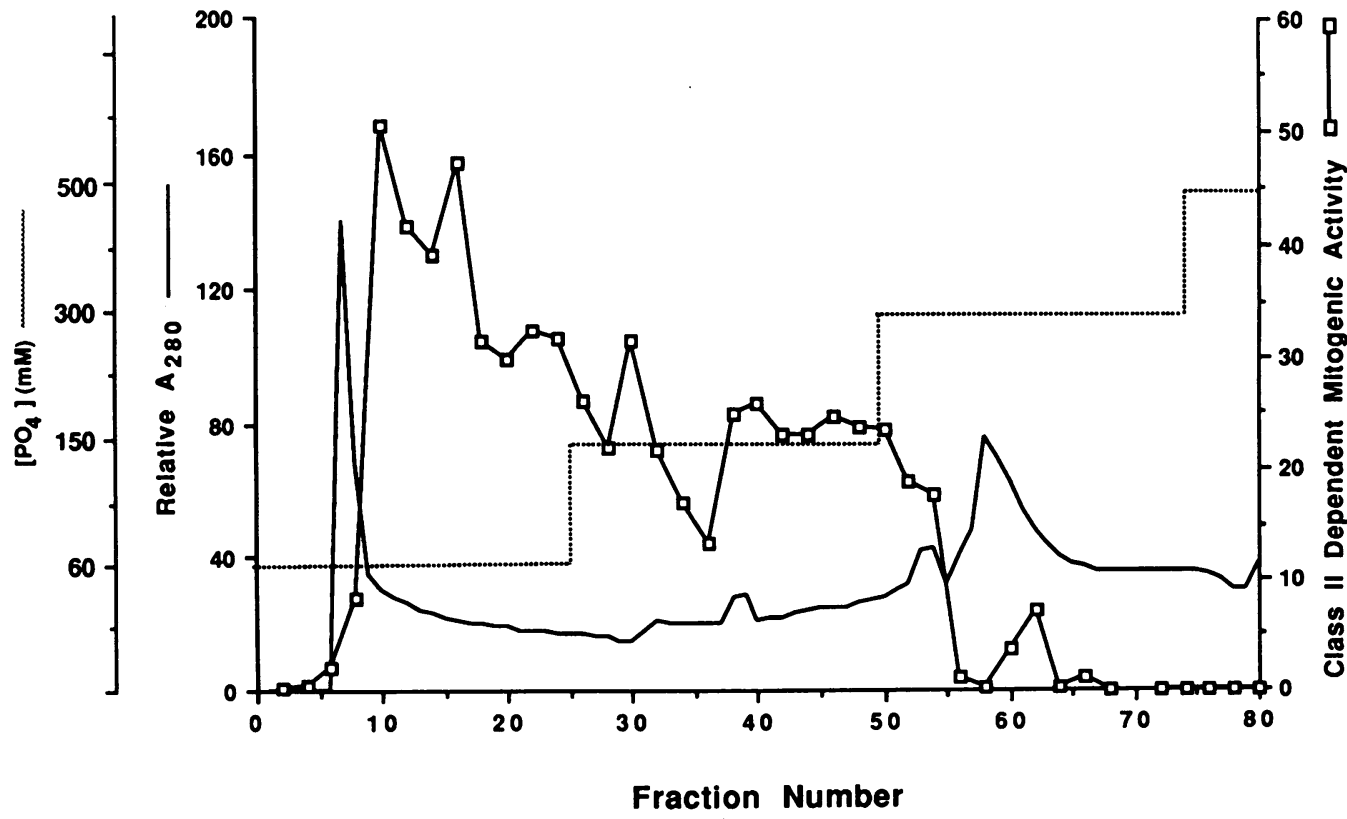

Figure 1. Identification of a streptococcal class II-dependent $T$ cell mitogen eluting from a RDA column. Supernatant ( 16 liters) from strain Weller was prepared and chromatographed on a RDA column. Fractions $(12 \mathrm{ml})$ were collected and $1 \mathrm{ml}$ of every other fraction was dialyzed against $50 \mathrm{mM}$ ammonium bicarbonate, lyophilized, and dissolved in $400 \mu \mathrm{l}$ of assay media. Assay media consisted of RPMI-1640, $10 \%$ human $\mathrm{AB}^{+}$serum, 2 mM L-glutamine, $1 \%$ antibiotic-antimycotic mixture, $100 \mu \mathrm{g} / \mathrm{ml}$ gentamicin and 5 mM Hepes. All components, except for serum were from Gibco Laboratories (Grand Island, NY). Samples were incubated, in duplicate, along

with $6 \times 10^{4}$ purified $\mathrm{T}$ cells and $3 \times 10^{4}$ mitomycin treated $\mathrm{L}$ cells that had been transfected with HLA-DR1 or left untransfected. T cell proliferation was determined at 3 days by an $18 \mathrm{~h}$ pulse with $\left[{ }^{3} \mathrm{H}\right]$ thymidine $(1 \mu \mathrm{Ci}$ per well $)$. To derive the class II-dependent mitogen index, the mean of duplicate cultures with untransfected $L$ cells was subtracted from the mean of duplicate cultures containing DR 1 -transfected L cells. Only background proliferation was observed in all cultures containing untransfected $\mathrm{L}$ cells indicating that all of the $\mathrm{T}$ cell mitogenic activity observed was class II-dependent. The units for this scale are given in $\left[{ }^{3} \mathrm{H}\right] \mathrm{TdR}\left(\mathrm{cpm} \times 10^{-3}\right)$. 
A

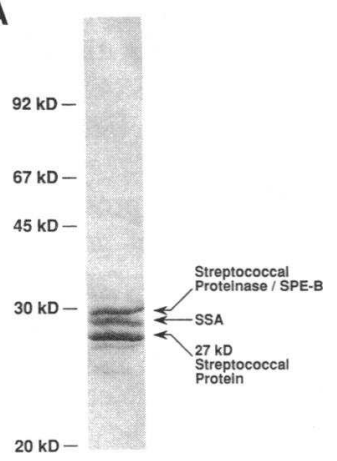

B

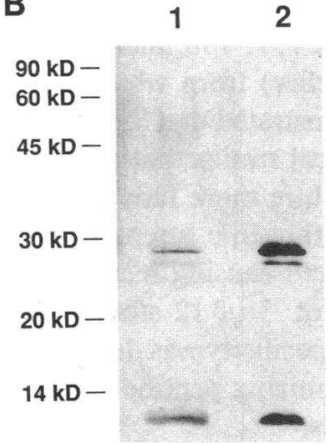

Figure 2. Analysis of SSA purification products by SDS-PAGE and immunoblot analysis. Two protocols were used to purify SSA: $(a)$ RDA, gel filtration (G-75) and anion exchange chromatography. (b) RDA and Ab affinity chromatography. $(A)$ Purification products from sequential chromatography protocol were electrophoresed, transfered to Problott and stained with Commassie Blue. The three major band were analyzed by $\mathrm{NH}_{2}$-terminal sequencing and their identity indicated by arrows. The $27-\mathrm{kD}$ protein had the sequence QTQVSNDVVLNDGASKYLNEALAWTFNDSPNYYKTLGTSQITPALFPKAGDILY()KLDE, with parenthesis indicating that this amino acid identification could not be made. Use of this sequence to probe GenPept, PIR, and SwissProt data bases for homology failed to find any identical or significantly homologous proteins. $(B)$ Products of anti-SSA Ab affinity purification analyzed by $12.5 \%$ SDS PAGE. Lane 1 , silver strain. The protein at $28 \mathrm{kD}$ was identified as SSA, by $\mathrm{NH}_{2}$-terminal sequencing. Lane 2, identical sample in lane $l$ transfered to nitrocellulose, probed with anti-SSA IgG and developed with chemiluminescence. Specificity of the bands in the immunoblot were demonstrated by blocking with SSA (1-19) peptide (data not shown).

HLA-DP or H-2 I-A (HLA tranfectants, Fig. $5 A$ and H-2 transfectants, Fig. $5 B$ ), a usage pattern similar to that exhibited by SEB $(25,27)$. From these data we conclude that like SEB, SSA has a "restricted" ability to utilize MHC class II isotypes.

SSA has a unique pattern of human VB-specific $T$ cell activation. In addition to class II binding specificity, bacterial superantigens exhibit unique patterns of $\mathrm{V} \beta$-specific $\mathrm{T}$ cell activation. To identify the human $\mathrm{V} \beta$ segments responsive to SSA, $\mathrm{V} \beta$ specific primers and PCR were used to analyze TCR expression in responding $T$ cells. Purified $T$ cells from two donors were stimulated with SSA, SEB, and PHA. RNA was isolated from the cells and subjected to reverse transcriptase / PCR analysis for TCR $\beta$ chains. Stimulation with PHA resulted in expansion of $\mathrm{T}$ cells bearing receptors derived from multiple $\mathrm{V}$ gene families (data not shown). Although some receptor families were more abundantly represented than others, no $V \beta$ family was predominant in PHA-stimulated cultures. In contrast,
SSA and SEB preferentially stimulated T cells expressing receptors derived from specific $\mathrm{V} \beta$ gene families. SEB showed predominant stimulation of $\mathrm{V} \beta 3$ - and lesser expansion of $\mathrm{V} \beta 17-, 12-$, and 15 -bearing $T$ cells, a result confirming previous data (20) (Fig. 6). The pattern of stimulation differed for SSA and showed striking expansion of $\mathrm{V} \beta 1-, 3-$, and 15-bearing $\mathrm{T}$ cells and minimal stimulation of cells expressing $\mathrm{V} \beta 5.2$. Hence, the $V \beta$ specificities of SSA and SEB are virtually distinct, and importantly, the $\mathrm{V} \beta$ specificity of SSA is unique compared to related enterotoxins and the pyrogenic exotoxins (Table I). In addition, SSA is the only bacterial superantigen known to activate human $\mathrm{V} \beta 1$.

SPE-A and SSA are antigenically distinct molecules. Four alleles of SPE-A have been described to date (28). Because recent work from our laboratory showed that the sites on SEA and SEE that mediate class II- and TCR binding activities localize to discrete domains in the $\mathrm{NH}_{2}$ - and $\mathrm{COOH}$-terminal regions, respectively, it is a formal possibility that SSA is an allelic variant of SPE-A that has acquired new class II binding and $\mathrm{V} \beta$-specificities through mutations of relatively few amino acids. Thus, past amino acid 24, SSA may begin to show more homology to SPE-A. We therefore probed SSA and SPE-A with antisera against the two proteins to look for antigenic relatedness. Anti-SPE-A antisera strongly detected SPE-A, but showed very little cross reactivity with SSA (Fig. 7). If SSA resembles SEB throughout the molecules, as its $\mathrm{NH}_{2}$ terminus suggests, then a small amount of cross-reactivity between antiSPE-A and SSA might be expected base on previous studies (29). A duplicate blot was also probed with anti-SSA and showed that anti-SSA does not detect SPE-A. This blot is not as informative as the reciprocal experiment because the antiSSA Abs used were raised against the amino-terminal 19 amino acids of SSA and thus can only give information about the immunological relatedness of the extreme $\mathrm{NH}_{2}$ termini of these two proteins. The strongest evidence that SSA and SPE-A are not allelic variants is the fact that SSA is produced by many strains that lack the speA gene (Table II).

Restriction of SSA production to S. pyogenes. To determine whether production of SSA is restricted to group A streptococci, eight strains of Lancefield group B, five strains of group $\mathrm{C}$ and three strains of group $\mathrm{G}$ streptococci were screened by immunoblot assay. We failed to identify evidence of SSA production by the non-group A streptococcal strains tested (data not shown), suggesting that expression is restricted to $S$. pyogenes.

Expression of SSA by pathogenic streptococci. If SSA contributes to the ability of group A Streptococcus to cause TSLS and other streptococcal diseases, then the presence of SSA or high levels of its production may be associated with strains that cause these diseases. To test this hypothesis, we screened cul-

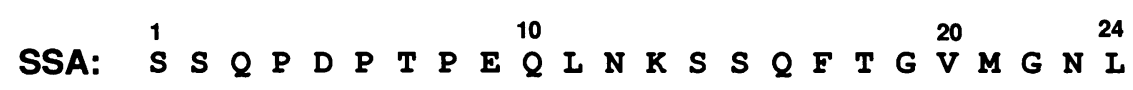

SEB: $\quad E----K-D E-H---K--I-E-M$

SEC $_{1}: \quad E$ - - - - - D E - H - A - K - - L - E - M

SPE-A: $Q$ Q D - - $-S$ Q I H R S S I V K N I Q N I Y F -

Figure 3. SSA amino acid comparison with SEB, $\mathrm{SEC}_{1}$, and SPE-A. Amino acids in the compared sequences identical to SSA are shown as dashes, differences are indicated.

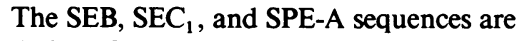
derived from the cloned gene sequences (see references 46-48) and represents the amino terminus of the mature (processed) molecule. Comparison to $\mathrm{SEC}_{1}$ is shown, however, significant homology to the $\mathrm{SEC}_{3} \mathrm{NH}_{2}$ terminus also exists. The $\mathrm{NH}_{2}$ terminus shown for $\mathrm{SSA}$ has been sequenced from both strains Weller and MGAS 158 and found to be identical.
} 


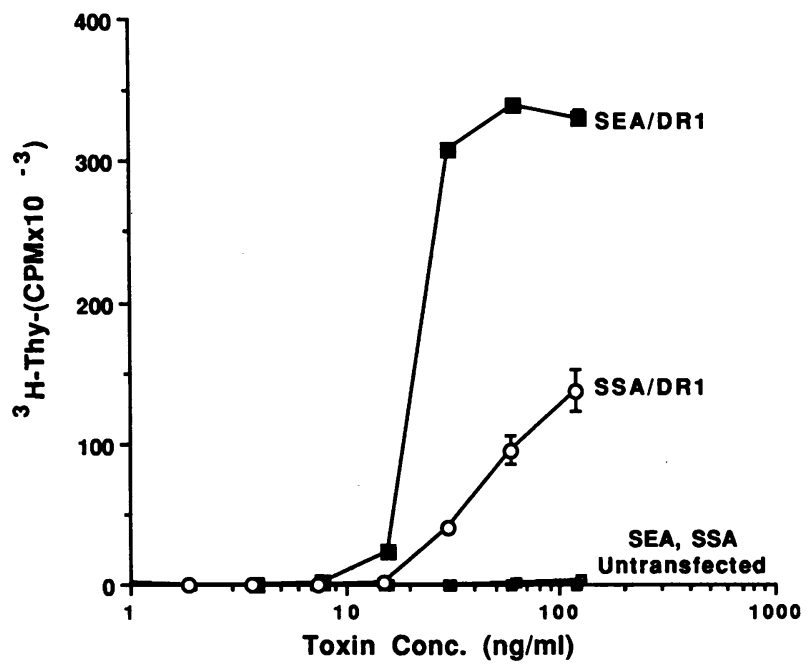

Figure 4. SSA is a potent class II-dependent T cell mitogen. SSA was prepared by $A b$ affinity chromatography and was identical to the material shown in Fig. $2 B$. SSA and SEA were incubated with 8 $\times 10^{4}$ purified $\mathrm{T}$ cells and $4 \times 10^{4}$ mitomicin-treated DR 1 -transfected $\mathrm{L}$ cells and proliferation was measured on day 3 by an 18-h pulse with $\left[{ }^{3} \mathrm{H}\right]$ thymidine $(1 \mu \mathrm{Ci}$ per well $)$. Error bars indicate the SEM of duplicate cultures.

ture supernatants from 12 strains of $S$. pyogenes for reactivity with rabbit anti-SSA Ab by immunoblot. Three of 12 strains cultured from patients with recent episodes of severe invasive disease or TSLS were positive (Fig. 8). Ab specificity was demonstrated by the ability of the immunizing peptide, SSA (119), but not a control peptide, to block the presence of these bands at $28 \mathrm{kD}$. Interestingly, there was some variation in the apparent level of SSA production by these strains. For example, strains 157,158 , and 159 produced more SSA than the strain (Weller) from which we initially isolated SSA. These data demonstrated that SSA was produced by some, but not all streptococcal strains that cause TSLS.

To explore more fully the distribution of SSA production among pathogenic streptococci, eleven strains of group A Streptococcus causing recurrent pharyngitis were screened by immunoblot. 3 of 12 strains produced SSA (Fig. 9). Again, antibody specificity was demonstrated by the ability of the specific immunizing peptide (SSA 1-19) to inhibit detection of these bands.

Expression of SSA is restricted to three streptococcal clonal lineages. Recent evidence has shown that one or a few clonal lineages of streptococci or staphylococci are responsible for the majority of the toxic shock diseases caused by these organisms $(15,30)$. Therefore, we screened 46 additional isolates from disease episodes and organized them according to clonal lineage. Table II shows that SSA was produced by $100 \%$ of the organisms screened in only three clonal lineages: ET2, ET14, and ET24. ET2 and ET14 lineages correspond to protein serotypes M3 and M4, respectively.

\section{Discussion}

Bacterial superantigens are thought to be causally involved in the pathogenesis of several acute and chronic human diseases (31). Elucidation of the molecular details of superantigen-mediated $\mathrm{T}$ cell activation has made it possible to study specific hypotheses about the consequences of exposure to these proteins. TSLS is thought to be caused, in part, by SPE-A $(3,15)$. However, the better-characterized example of a superantigenmediated disease is staphylococcal TSS, induced by TSST-1
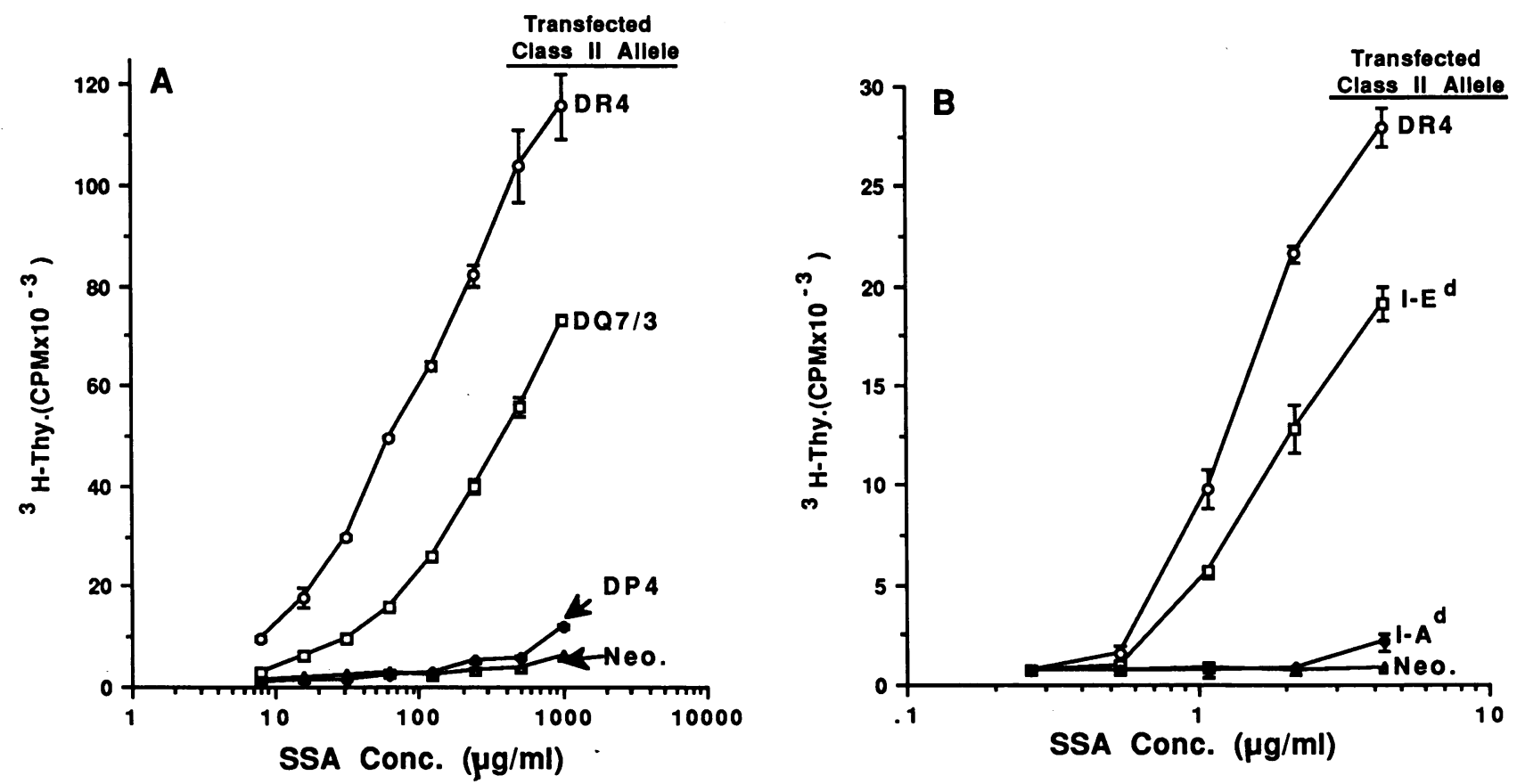

Figure 5. MHC class II isotype usage of SSA resembles that of SEB. Partially purified SSA was incubated with highly purified human T cells and mitomycin-treated mouse L cells transfected with the indicated HLA or H-2 class II isotypes, as described (7). The abscissa reflects total protein content of the partially purified SSA sample and thus underestimates the true specific activity of SSA in this assay. Proliferation was measured on day 3 by an 18 -h pulse with $\left[{ }^{3} \mathrm{H}\right]$ thymidine $(1 \mu \mathrm{Ci}$ per well $)$. Error bars indicate the SEM of triplicate cultures. 

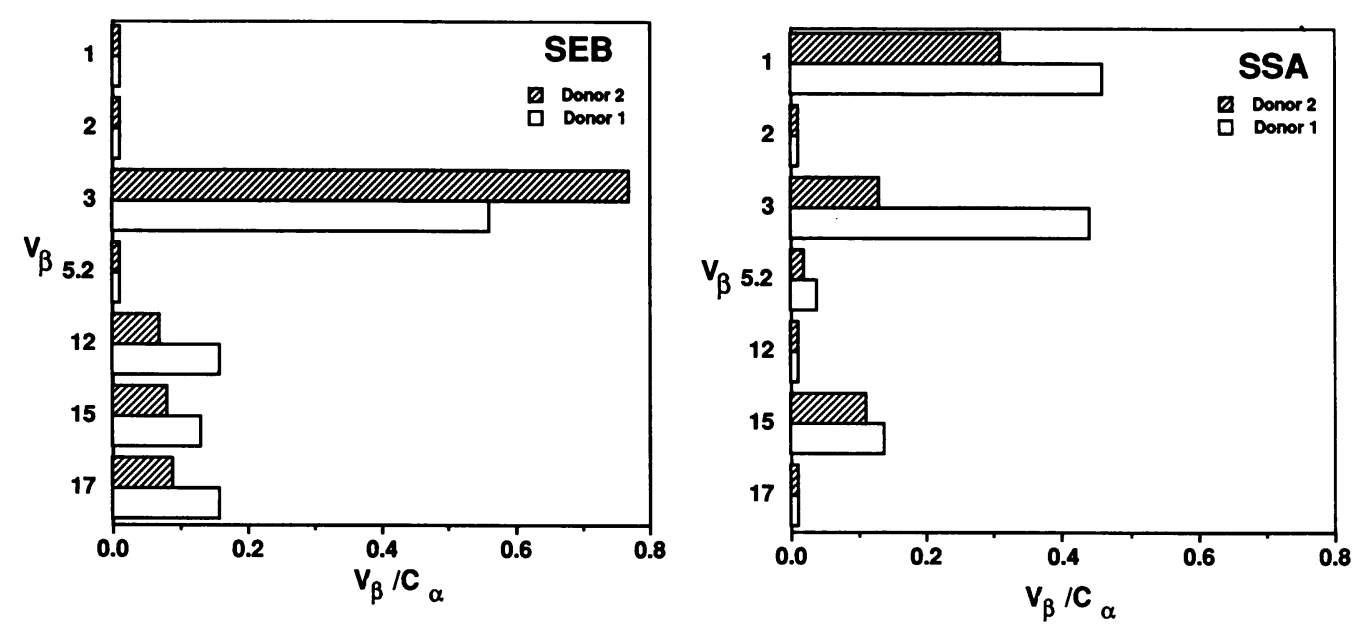

Figure 6. Analysis of SSA-activated $T$ cell blasts by quantitative PCR measurement of $\mathrm{V} \beta$ mRNA. SSA or SEB was incubated with purified $T$ cells $\left(1 \times 10^{6} / \mathrm{ml}\right)$ and mitomycin-treated DR 1-transfected $\mathrm{L}$ cells $\left(2.5 \times 10^{6} / \mathrm{ml}\right)$ for $3 \mathrm{~d}$ at $37^{\circ} \mathrm{C}$ in a total of $10 \mathrm{ml}$ of assay media. Viable cells were isolated on an isolymph gradient and the cells cultured overnight in assay media and $25 \mathrm{U} / \mathrm{ml}$ recombinant IL-2. Cells were harvested and the pellets stored at $-70^{\circ} \mathrm{C}$. Total cellular RNA was isolated, reverse transcribed into cDNA and quantitative PCR carried out as described by Choi et al. (20). All V $\beta$ s screened and not illustrated showed no elevation over background.
(32-34). Although toxins play a critical role in the evolution of these diseases, the clone of the organism carrying the toxin (30) as well as a number of host factors such as the presence of circulating anti-toxin Abs are also important.

Two of the major goals of this study were to definitively assign the superantigen activity we found to the molecule and to differentiate SSA, structurally and functionally, from previously characterized staphylococcal or streptococcal superantigens. Controversy exists regarding the assignment of superantigen activity to several staphylococcal and streptococcal molecules, including SPE-B (35), due to possible contaminants in the preparations $(36,37)$. Assignment of $\mathrm{V} \beta$ specificities to certain superantigens has apparently also suffered from use of contaminated samples (5). Therefore, we felt it important to purify SSA to apparent homogeneity. Sequential chromatography on RDA and Ab affinity columns was used to prepare purified SSA. The final material migrated as a $28-\mathrm{kD}$ band on silver stained SDS-PAGE gel with two minor breakdown products and exhibited class II-dependent $T$ cell mitogenic activity at concentrations $<50 \mathrm{ng} / \mathrm{ml}$, consistent with the characteristics and potency of superantigens.

We differentiated SSA from streptococcal exotoxins, particularly SPE-A and M protein, by four independent techniques. The protein sequence data demonstrated that SSA possessed a

Table I. Comparison of Vß Specificities of Selected Staphylococcal and Streptococcal Superantigens

\begin{tabular}{lccc}
\hline Superantigen & $\begin{array}{c}\text { V } \beta \text {-bearing } \\
\text { T cells activated }\end{array}$ & $\begin{array}{c}\text { Methodology used } \\
\text { for determination }\end{array}$ & Reference \\
\hline SSA & $1,3,15^{*}$ & Quantitative PCR & This work \\
SPE-A & $8,12,14$ & Quantitative PCR & 12 \\
SPE-B & 2,8 & Quantitative PCR & 12 \\
SEB & $3,12,15,17$ & Quantitative PCR & 20 \\
SEC & 5,12 & V $\beta$ Specific Antibodies & 45 \\
\hline
\end{tabular}

* SSA also activated low levels of V $\beta 5.2$ in two donors. novel $\mathrm{NH}_{2}$ terminus that was closely similar to, but distinct from, SEB and $\mathrm{SEC}_{1,3}$ and was quite divergent from the $\mathrm{NH}_{2}$ termini of SPE-A, -B, and -C. SSA exhibited no homology to the $\mathrm{NH}_{3}$ terminus of streptococcal M protein. Second, SSA had a pattern of class II isotype usage that was similar to SEB, but different from those for SPE-A $(11,12)$. Third, SSA and SEB activated distinct $\mathrm{V} \beta$-specific subsets of $\mathrm{T}$ cells, a result effectively ruling out the possibility that SSA was a minor variant of $\mathrm{SEB}$ or $\mathrm{SEC}_{1,3}$. Studies have mapped the class II binding activity of SEA and SEB to the $\mathrm{NH}_{2}$-terminal region $(38,39)$. In contrast, recent work from our laboratory showed exchangemutations between SEA and SEE involving as few as three amino acids in the extreme carboxy terminal region can transfer most $\mathrm{V} \beta$ specificity between these two superantigens (40). It is possible that the gene encoding SSA is a chimera, the result of a recombination event between the $5^{\prime}$ region of the SEB gene and the $3^{\prime}$ region of a second superantigen gene, thus imparting a new pattern of $\mathrm{V} \beta$-specific $\mathrm{T}$ cell activation on

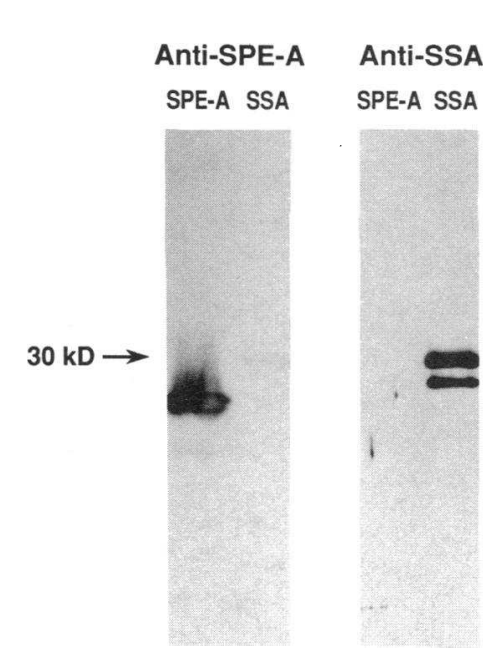

Figure 7. SSA and SPE-A are antigenically distinct molecules. SSA and SPE-A $(\sim 0.5 \mu \mathrm{g}$ per lane $)$ were electrophoresed on a $10 \%$ SDS-PAGE gel, blotted to nitrocellulose, blocked, and probed with either antiSPE-A antisera $(1: 4,000$ dilution) or anti-SSA Ig ( 1 $\mu \mathrm{g} / \mathrm{ml}$ ) overnight. The blots were washed and further probed with biotinylated goat anti-rabbit Ig followed by streptavidinhorse radish peroxidase and developed using the ECL chemiluminescence system (Amersham Corp.). 
Table II. Summary of SSA Production by Group A Streptococcal Strains

\begin{tabular}{|c|c|c|c|c|c|c|}
\hline $\begin{array}{l}\text { MGAS } \\
\text { strain }\end{array}$ & $\begin{array}{l}\text { Exotoxin } \\
\text { production }\end{array}$ & $\begin{array}{l}\text { SPE-A } \\
\text { probe }\end{array}$ & Disease & $\begin{array}{l}\text { Protein } \\
\text { serotype }\end{array}$ & $\begin{array}{c}\text { Electrophoretic } \\
\text { type }\end{array}$ & $\begin{array}{c}\text { SSA } \\
\text { production }\end{array}$ \\
\hline 22 & None & $\mathrm{nt}^{*}$ & pharyngitis & M1 & 1 & - \\
\hline 36 & A & nt & pharyngitis & M1 & 1 & - \\
\hline 39 & None & $\mathrm{nt}$ & pharyngitis & M1 & 1 & - \\
\hline 64 & None & nt & pharyngitis & M1 & 1 & - \\
\hline 166 & A & + & TSLS $^{\ddagger}$ & M1 & 1 & $+1-8$ \\
\hline 256 & $\mathrm{~B}, \mathrm{C}$ & + & SID & & 1 & - \\
\hline 267 & B & - & SID & M1 & 1 & - \\
\hline 279 & B & - & SID & M1 & 1 & - \\
\hline 287 & $A, B, C$ & + & SID & M1 & 1 & - \\
\hline 290 & A, B & + & SID & M1 & 1 & - \\
\hline $294^{\prime \prime}$ & A & + & TSLS & M1 & 1 & - \\
\hline 297 & $\mathrm{~A}, \mathrm{~B}, \mathrm{C}$ & + & TSLS & M1 & 1 & - \\
\hline 301 & A, B & + & TSLS & M1 & 1 & - \\
\hline 307 & A, B & + & TSLS & M1 & 1 & - \\
\hline 309 & A, B & + & TSLS & M1 & 1 & - \\
\hline 312 & A, B & + & TSLS & M1 & 1 & - \\
\hline 313 & A, B & + & TSLS & M1 & 1 & $+1-$ \\
\hline 314 & A, B & + & Invasive & M1 & 1 & - \\
\hline 326 & $\mathrm{C}$ & - & TSLS & M1 & 1 & - \\
\hline 337 & A, B & + & Invasive & M1 & 1 & - \\
\hline 340 & A & + & TSLS & M1 & 1 & - \\
\hline Weller' & A & nt & TSLS & M3 & 2 & $++^{* *}$ \\
\hline 58 & None & nt & pharyngitis & M3 & 2 & ++ \\
\hline 157 & A & + & TSLS & M3 & 2 & +++ \\
\hline 158 & A & + & TSLS & M3 & 2 & +++ \\
\hline 159 & A & + & TSLS & M3 & 2 & +++ \\
\hline 160 & A & + & TSLS & M3 & 2 & ++ \\
\hline 161 & A & + & TSLS & M3 & 2 & ++ \\
\hline 268 & A & + & TSLS & M3 & 2 & +++ \\
\hline 271 & A & + & TSLS & & 2 & +++ \\
\hline 272 & A, B & + & TSLS & M3 & 2 & +++ \\
\hline 274 & $\mathrm{~A}, \mathrm{~B}, \mathrm{C}$ & + & SID & M3 & 2 & +++ \\
\hline 292 & A & + & SID & M3 & 2 & + \\
\hline 315 & A, B & + & TSLS & M3 & 2 & +++ \\
\hline 322 & A & + & TSLS & M3 & 2 & +++ \\
\hline 335 & A & + & Invasive & M3 & 2 & + \\
\hline 270 & $\mathrm{~B}, \mathrm{C}$ & - & SID & nt & 3 & - \\
\hline 261 & $\mathrm{C}$ & - & SID & nt & 4 & - \\
\hline 163 & A & + & TSLS & nt & 5 & - \\
\hline 295 & B & - & Invasive & $\mathrm{T} 9 / 14$ & 5 & - \\
\hline 37 & None & nt & pharyngitis & M4 & 14 & ++ \\
\hline 62 & None & nt & pharyngitis & M4 & 14 & ++ \\
\hline 281 & $\mathrm{nr}^{\ddagger \ddagger}$ & - & SID & $\mathrm{T} 4$ & 14 & +++ \\
\hline 299 & $\mathrm{~B}, \mathrm{C}$ & - & Invasive & M4 & 14 & +++ \\
\hline 318 & $\mathrm{nr}$ & - & Invasive & $\mathrm{T} 4$ & 14 & +++ \\
\hline 320 & B & - & Invasive & M4 & 14 & +++ \\
\hline 321 & B, C & - & TSLS & M4 & 14 & +++ \\
\hline 167 & $\mathrm{~A}, \mathrm{~B}, \mathrm{C}$ & + & TSLS & M66 & 16 & - \\
\hline 156 & A, C & + & TSLS & M18 & 20 & - \\
\hline 278 & B & - & SID & M12 & 21 & - \\
\hline 275 & B & - & SID & $\mathrm{T} 12$ & 24 & ++ \\
\hline 260 & $\mathrm{C}$ & - & SID & nt & 27 & - \\
\hline 12 & $\mathrm{C}$ & nt & pharyngitis & M3 & not ET2 & - \\
\hline 16 & $\mathrm{C}$ & $\mathrm{nt}$ & pharyngitis & nt & $\mathrm{nt}$ & $+1-$ \\
\hline 30 & None & $\mathrm{nt}$ & pharyngitis & nt & nt & - \\
\hline
\end{tabular}


Table II. (Continued)

\begin{tabular}{rlllllc}
\hline $\begin{array}{c}\text { MGAS } \\
\text { strain }\end{array}$ & $\begin{array}{c}\text { Exotoxin } \\
\text { production }\end{array}$ & $\begin{array}{c}\text { SPE-A } \\
\text { probe }\end{array}$ & Disease & $\begin{array}{c}\text { Protein } \\
\text { serotype }\end{array}$ & $\begin{array}{c}\text { Electrophoretic } \\
\text { type }\end{array}$ & SSA \\
production
\end{tabular}

* nt, not tested.

${ }^{\ddagger}$ TSLS, toxic shock-like syndrome. SID, severe invasive disease. Disease categories are defined as in reference 15. For other isolates studied, insufficient clinical information was available to permit assignment to either disease category TSLS or SID, and therefore are labeled only as invasive. ${ }^{8}$ Designates faint bands estimated to be 20-50 times less intense than the reference strain, Weller, and of slightly lower $M_{\mathrm{r}}$. The bands were blockable by the addition of specific peptide, SSA (1-19).

"MGAS 294 and strain Gall are identical. Strain Gall is also designated by strain number DLS89026.

'Strain Weller also carries the designation DLS88002.

** Designates relative intensity of bands, as judged by visual inspection, compared to strain Weller: ++ , same intensity as strain Weller; +++ , more intense than strain Weller; and + , less intense than strain Weller.

${ }^{\sharp} \mathrm{nr}$, nonresponsive with antisera directed against SPE-A, -B, and -C.

SEB. A precedent for recombination involving toxin genes exists $(41)$.

One intriguing feature of SSA is the fact that it apparently is more similar to certain staphylococcal exotoxins than to any streptococcal pyrogenic exotoxin. The use of RDA chromatography in our purification protocol may have provided an essential advantage in separating SSA from SPE-A and SPE-C. RDA has been shown to be an effective means of purifying virtually all staphylococcal enterotoxins $(23,24)$. Given the striking resemblance of the $\mathrm{NH}_{2}$ terminus of SSA to SEB and SEC ${ }_{1,3}$, it is not surprising that SSA was also amenable to RDA purification. We never identified more than one peak of class II-dependent mitogenic activity in any of the chromatography steps subsequent to RDA, nor have any of the proteins sequenced revealed contamination with SPE-A or SPE-C. In addition, analysis of relatively crude post-RDA fractions for $\mathrm{V} \beta$-specific $T$ cell activation revealed no expansion of $T$ cells bearing $V \beta$ gene segments reported to be responsive to SPE-A or SPE-C $(11,12)$. Therefore, we tentatively conclude that SPE-A and SPE-C do not bind RDA, although we have not tested this directly.

SSA was detected in all ET2 and ET14 streptococci, which express serotype M3 and M4, respectively. We also identified SSA production in a single ET24 isolate. Because we have tested only one ET24 organism, we cannot determine whether or not $(a)$ this one strain is an exception or $(b)$ ET24 represents a third clonal lineage that uniformly expresses SSA. The restriction of SSA production in our survey to only two or three

\section{MGAS

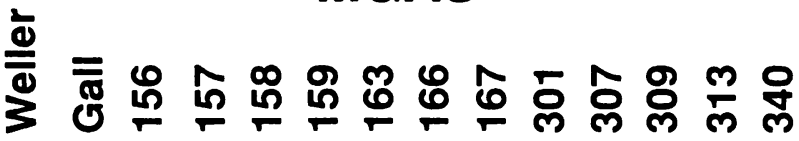

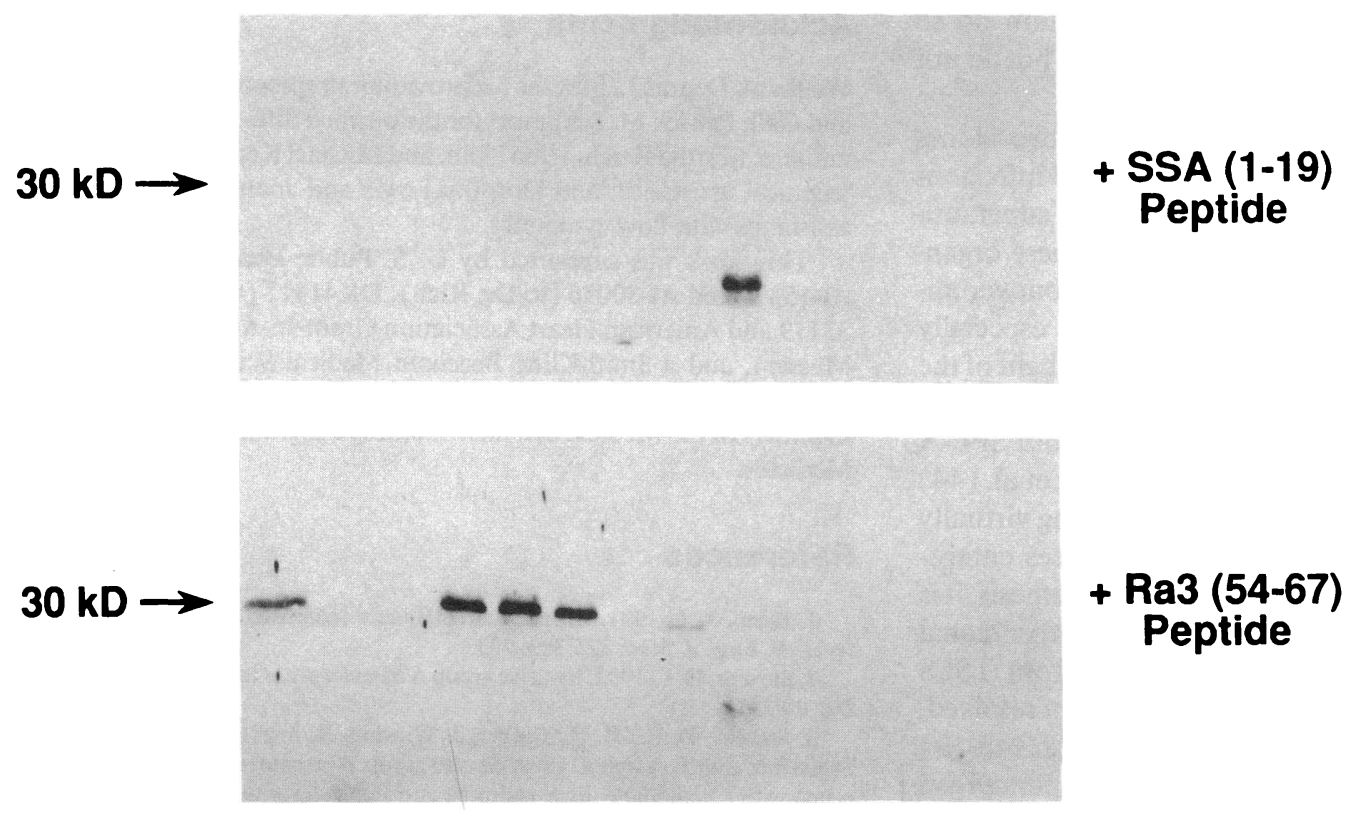

Figure 8. SSA production in diverse group A streptococcal clones that cause TSLS. See Table II for details concerning serotype and electrophoretic type of the clones. Streptococcal culture supernatants were concentrated 10-fold, separated by SDSPAGE, blotted to nitrocellulose, and probed overnight with anti-SSA IgG conjugated to horseradish peroxidase and developed with chemiluminescence. 


\section{MGAS

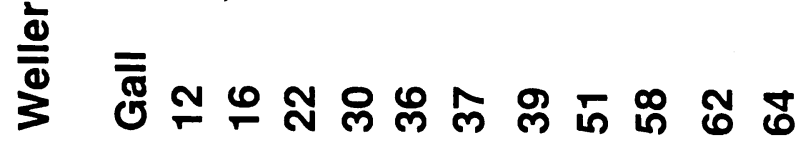

$30 \mathrm{kD} \rightarrow$

\section{+ SSA (1-19) Peptide}

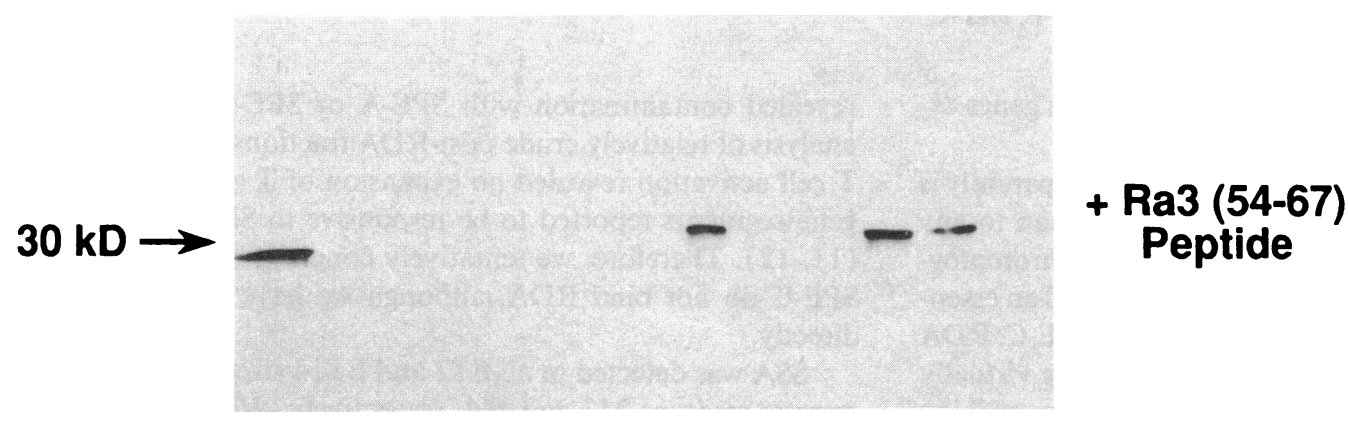

Figure 9. SSA production in group A streptococcal clones isolated from patients with recurrent pharyngitis. See Fig. 8 legend for experimental details.
S. pyogenes clonal lineages has several molecular evolutionary implications. First, such striking restriction to two clonal lineages suggests that SSA may be evolutionarily new, compared to SPE-B, SPE-C, and even SPE-A, whose expression are much more widely distributed among different clones (15). Second, the occurrence of SSA in two divergent streptococcal clonal lineages suggests that SSA, like the pyrogenic exotoxins, is encoded by a phage and is capable of horizontal transfer between different clones $(28,42)$. Without a Southern blot to probe the presence or absence of the structural gene for SSA, we cannot determine if the clones that lack SSA expression do so because they lack the SSA gene or they have the gene but do not express it.

It is important to understand why isolates of two clones account for most episodes of invasive streptococcal infections (15). One hypothesis is that additive expression of superantigens imparts a graded pathogenic phenotypes to these organisms (43). The fact that SSA and SPE-A stimulate nonoverlapping $\mathrm{T}$ cell subsets might make this combination especially virulent. This possibility is made more interesting in light of the fact that many of the ET2 clones, one of the two clonal lineages that causes the majority of TSLS cases, produces both SPE-A and SSA. In this regard, it is noteworthy that Chang et al. (44) recently discovered that the clone of $S$. aureus causing virtually all episodes of TSS with a urogenital focus produces enterotoxin A (SEA) as well as TSST-1. In light of this hypothesis, it is appropriate to ask why SSA is not produced by the other clonal lineage recovered with relatively high frequency from TSLS patients, ET1 or M1. Although this question is not yet resolved, we have recently shown that two ET1 strains, Gall (MGAS 294 or DLS 89026) and MGAS 166 both produce a superantigen that adheres to RDA and elutes from an anion exchange col- umn at approximately the same position as SSA (J. Mollick, J. Lamphear, and R. Rich, unpublished observation). This superantigen is likely not SPE-A because the failure of SPE-A to adhere to RDA, and is not SSA, based on our immunoblot data demonstrating that SSA is not produced by ET1 organisms. Identification of a novel, ET 1-specific exotoxin would support the hypothesis that additive production of superantigens by $S$. pyogenes favors their ability to cause more severe disease in humans.

\section{Acknowledgments}

We thank Dennis L. Stevens for providing streptococcal strains Weller and Gall; Patrick M. Schlievert for the purified SPE-A and anti-SPE-A antisera; Martha Reich, Uma Shah, and Michael Kennedy for excellent technical assistance; and Dorothy Lewis and Joanne Thompson for assistance with flow cytometry.

This work was supported by U. S. Public Health Service grants AI-15394 and AI-30036 (to Dr. Rich), DK41312 (to Dr. Miller), AI33119 and American Heart Association Grant-In-Aid 92-6640 (to Dr. Musser), and a SmithKline Beecham Medical Scientist Predoctoral Fellowship (to J. A. Mollick). J. A. Mollick and D. Grossman are members of the Medical Scientist Training Program, Baylor College of Medicine.

\section{References}

1. Bisno, A. L. 1991. Group A streptococcal infections and acute rheumatic fever. N. Engl. J. Med. 325:783-793.

2. Stevens, D. L. 1992. Invasive group A Streptococcus infections. Clin. Infect. Dis. 14:2-11.

3. Stevens, D. L., M. H. Tanner, J. Winship, R. Swarts, K. M. Ries, P. M. Schlievert, and E. Kaplan. 1989. Severe group A streptococcal infections associated with a toxic shock-like syndrome and scarlet fever toxin. N. Engl. J. Med. 321:1-7. 
4. Marrack, P. C., and J. W. Kappler. 1990. The staphylococcal enterotoxins and their relatives. Science (Wash. DC). 248:705-711.

5. Herman, A., J. W. Kappler, P. Marrack, and A. M. Pullen. 1991. Superantigens: mechanisms of T-cell stimulation and role in immune responses. Annu. Rev. Immunol. 9:745-772.

6. Fleischer, B. 1991. Stimulation of human T cells by microbial 'superantigens'. Immunol. Res. 10:349-355.

7. Mollick, J. A., R. G. Cook, and R. R. Rich. 1989. Class II MHC molecules are specific receptors for staphylococcal enterotoxin A. Science (Wash. DC). 244:817-820.

8. Fraser, J. D. 1989. High affinity binding of staphylococcal enterotoxins A and B to HLA-DR. Nature (Lond.). 339:221-223.

9. Marrack, P., M. Blackman, E. Kushnir, and J. Kappler. 1990. The toxicity of staphylococcal enterotoxin B in mice is mediated by T cells. J. Exp. Med. 171:455-462.

10. Hackett, S. P., and D. L. Stevens. 1992. Streptococcal toxic shock syndrome: synthesis of tumor necrosis factor and interleukin-1 by monocytes stimulated with pyrogenic exotoxin A and streptolysin O. J. Infect. Dis. 165:879-885.

11. Imanishi, K., H. Igarashi, and T. Uchiyama. 1990. Activation of murine T cells by streptococcal pyrogenic exotoxin type A: requirement for MHC class II molecules on accessory cells and identification of $\mathrm{V} \beta$ elements in $\mathrm{T}$ cell receptor of toxin-reactive T cells. J. Immunol. 145:3170-3176.

12. Abe, J., J. Forrester, T. Nakahara, J. A. Lafferty, B. L. Kotzin, and D. Y. M. Leung. 1991. Selective stimulation of human T cells with streptococcal erythrogenic toxins A and B. J. Immunol. 146:3747-3750.

13. Tomai, M. A., P. M. Schlievert, and M. Kotb. 1992. Distinct T-cell receptor $\mathrm{V}$ beta gene usage by human $\mathrm{T}$ lymphocytes stimulated with the streptococcal pyrogenic exotoxins and pep M5 protein. Infect. Immun. 60:701-705.

14. Hauser, A. R., and P. M. Schlievert. 1990. Nucleotide sequence of the streptococcal pyrogenic exotoxin type B gene and relationship between the toxin and the streptococcal proteinase precursor. J. Bacteriol. 172:4536-4542.

15. Musser, J. M., A. R. Hauser, M. H. Kim, P. M. Schlievert, K. Nelson, and R. K. Selander. 1991. Streptococcus pyogenes causing toxic shock-like syndrome and other invasive diseases: clonal diversity and pyrogenic exotoxin expression. Proc. Natl. Acad. Sci. USA. 88:2668-2672.

16. Musser, J. M., B. M. Gray, P. M. Schlievert, and M. E. Pichichero. 1992. Streptococcus pyogenes pharyngitis: characterization of strains by multilocus enzyme genotype, $\mathbf{M}$ and $\mathrm{T}$ protein serotype, and pyrogenic exotoxin gene probing. J. Clin. Microbiol. 30:600-603.

17. Musser, J. M., S. J. Mattingly, R. Quentin, A. Goudeau, and R. K. Selander. 1989. Identification of a high-virulence clone of type III Streptococcus agalactiae (group B Streptococcus) causing invasive neonatal disease. Proc. Natl. Acad. Sci. USA. 86:4731-4735.

18. Simpson, W. J., J. M. Musser, and P. P. Cleary. 1992. Evidence consistent with horizontal transfer of the gene (emm12) encoding serotype M12 protein between group A and group $\mathrm{G}$ pathogenic streptococci. Infect. Immun. 60:18901893.

19. Chomczynski, P., and N. Sacchi. 1987. Single-step method of RNA isolation by acid guanidinium thiocyanate-phenol-chloroform extraction. Anal. Biochem. 162:156-159.

20. Choi, Y., B. Kotzin, L. Herron, J. Callahan, P. Marrack, and J. Kappler 1989. Interaction of Staphylococcus aureus toxin "superantigen" with human T cells. Proc. Natl. Acad. Sci. USA. 86:8941-8945.

21. Towbin, H., T. Staehelin, and J. Gordon. 1979. Electrophoretic transfer of proteins from polyacrylamide gels to nitrocellulose sheets: procedure and some applications. Proc. Natl. Acad. Sci. USA. 76:4350-4354.

22. Atassi, H., and M. Z. Atassi. 1986. Antibody recognition of ragweed allergen Ra3: localization of the full profile of the continuous antigenic sites by synthetic overlapping peptides representing the entire protein chain. Eur. J. Immunol. 16:229-235.

23. Tranter, H. S., and R. D. Brehm. 1990. Production, purification and identification of the staphylococcal enterotoxins. Soc. Appl. Bacteriol. Symp. Ser. 19:109S-111S.

24. Reynolds, D., H. S. Tranter, R. Sage, and P. Hambleton. 1988. Novel method for purification of staphylococcal enterotoxin A. Appl. Environ. Microbiol. 54:1761-1765.

25. Mollick, J. A., M. Chintagumpala, R. G. Cook, and R. R. Rich. 1990. Staphylococcal exotoxin activation of T cells: role of exotoxin-MHC class II binding affinity and class II isotype. J. Immunol. 146:463-468.
26. Scholl, P. R., A. Diez, R. Karr, R. P. Sekaly, J. Trowsdale, and R. S. Geha. 1990. Effect of isotypes and allelic polymorphisms on the binding of staphylococcal exotoxins to MHC class II molecules. J. Immunol. 144:226-230.

27. Yagi, J., J. Baron, S. Buxser, and C. A. Janeway, Jr. 1990. Bacterial proteins that mediate the association of a defined subset of $T$ cell receptor:CD4 complexes with class II MHC. J. Immunol. 144:892-901.

28. Nelson, K., P. M. Schlievert, R. K. Selander, and J. M. Musser. 1991. Characterization and clonal distribution of four alleles of the speA gene encoding pyrogenic exotoxin A (scarlet fever toxin) in Streptococcus pyogenes. J. Exp. Med. 174:1271-1274.

29. Bohach, G. A., C. J. Hovde, J. P. Handley, and P. M. Schlievert. 1988. Cross-neutralization of staphylococcal and streptococcal pyrogenic toxins by monoclonal and polyclonal antibodies. Infect. Immun. 56:400-404.

30. Musser, J. M., P. M. Schlievert, A. W. Chow, P. Ewan, B. N. Kreiswirth, V. T. Rosdahl, A. S. Naidu, W. Witte, and R. K. Selander. 1990. A single clone of Staphylococcus aureus causes the majority of cases of toxic shock syndrome. Proc. Natl. Acad. Sci. USA. 87:225-229.

31. Drake, C. G., and B. L. Kotzin. 1992. Superantigens: biology, immunology, and potential role in disease. J. Clin. Immunol. 12:149-162.

32. Todd, J. K. 1988. Toxic shock syndrome. Clin. Microbiol. Rev. 1:432436

33. Chesney, P. J. 1989. Clinical aspects and spectrum of illness of toxic shock syndrome: overview. Rev. Infect. Dis. 11(Suppl. 1):S1-S7.

34. Choi, Y., J. A. Lafferty, J. R. Clements, J. K. Todd, E. W. Gelfand, J. Kappler, P. Marrack, and B. L. Kotzin. 1990. Selective expansion of T cells expressing V $\beta 2$ in toxic shock syndrome. J. Exp. Med. 172:981-984.

35. Braun, M. A., D. Gerlach, U. F. Hartwig, J. H. Ozegwski, F. Romagné, S. Carrel, W. Köhler, and B. Fleischer. 1993. Stimulation of human T cells by streptococcal "superantigen" erythrogenic toxins (scarlet fever toxins). J. Immunol. 150:2457-2466.

36. Fleischer, B., K. H. Schmidt, D. Gerlach, and W. Köhler. 1992. Separation of T-cell-stimulating activity from streptococcal M Protein. Infect. Immun. 60:1767-1770.

37. Fleischer, B., and C. J. Bailey. 1992. Recombinant epidermolytic (exfoliative) toxin A of Staphylococcus aureus is not a superantigen. Med. Microbiol. Immunol. 180:273-278.

38. Kappler, J. W., A. Herman, J. Clements, and P. Marrack. 1992. Mutations defining functional regions of the superantigen staphylococcal enterotoxin B. J. Exp. Med. 175:387-396.

39. Pontzer, C. H., J. K. Russell, and H. M. Johnson. 1989. Localization of an immune functional site on staphylococcal enterotoxin A using the synthetic peptide approach. J. Immunol. 143:280-284.

40. Mollick, J. A., R. L. McMasters, D. Grossman, and R. R. Rich. 1993. Localization of a site on bacterial superantigens that determines $\mathrm{T}$ cell receptor $\beta$ chain specificity. J. Exp. Med. 177:283-293.

41. Couch, J. L., and M. J. Betley. 1989. Nucleotide sequence of the type C3 staphylococcal enterotoxin gene suggests that intergenic recombination causes antigenic variation. J. Bacteriol. 171:4507-4510.

42. Kapur, V., K. Nelson, P. M. Schlievert, R. K. Selander, and J. M. Musser. 1992. Molecular population genetic evidence of horizontal spread of two alleles of the pyrogenic exotoxin $\mathrm{C}$ gene (speC) among pathogenic clones of Streptococcus pyogenes. Infect. Immun. 60:3513-3517.

43. Knöll, H., J. Srámek, K. Vrboná, D. Gerlach, W. Reichardt, and W. Köhler. 1991. Scarlet fever and types of erythrogenic toxins produced by the infecting streptococcal strains. Intl. J. Med. Micro. 276:94-98.

44. Chang, A., J. M. Musser, and A. W. Chow. 1991. A single clone of $S$. aureus which produces both TSST-1 and SEA causes the majority of menstual toxic shock syndrome. Clin. Res. 39:36A. (Abstr.)

45. Kappler, J., B. Kotzin, L. Herron, E. Gelfand, R. Bigler, A. Boyston, S Carrel, D. Posnet, Y. Choi, and P. Marrack. 1989. V $\beta$-specific stimulation of human T cells by staphylococcal toxins. Science (Wash. DC). 244:811-813.

46. Jones, C. L., and S. A. Khan. 1986. Nucleotide sequence of the enterotoxin B gene from Staphylococcus aureus. J. Bacteriol. 166:29-33.

47. Bohach, G. A., and P. M. Schlievert. 1987. Nucleotide sequence of the staphylococcal enterotoxin $\mathrm{Cl}$ gene and relatedness to other pyrogenic toxins. Mol. Gen. Genet. 209:15-20.

48. Weeks, C. R., and J. J. Ferretti. 1986. Nucleotide sequence of the type Astreptococcal exotoxin (erythrogenic toxin) gene from Streptococcus pyogenes bacteriophage T12. Infect. Immun. 52:144-150. 